\title{
O silêncio em Jesus de Nazaré: redescobrindo o Deus silencioso para o discipulado hoje
}

\author{
Orientadora: Lúcia Pedrosa de Pádua \\ Mestranda: Alessandra Ayrão Martins \\ Área de Concentração: Teologia Sistemático-Pastoral
}

Linha de Pesquisa: Religião e Modernidade

A presente dissertação intitulada: O silêncio em Jesus de Nazaré: redescobrindo o Deus silencioso para o discipulado hoje foi desenvolvida com o objetivo de descobrir o significado do silêncio na vida de Jesus, para então redescobrir uma nova imagem de Deus, a partir do silêncio, à ser aplicada na dinâmica do discipulado hoje. A luz do referencial bibliográfico levantado percebeu-se que as igrejas precisam retornar a prática do silêncio nas suas mais variadas formas de vivê-lo para redescobrir o Deus silencioso de Jesus, porque Jesus pediu silêncio, respondeu com silêncio e ouviu a resposta silenciosa de Deus em sua vida, ensinando que assim deve ser na vida do seu discípulo.

Palavras-chave: Silêncio, palavra, meditação, Jesus de Nazaré, discipulado, discípulo. 